\title{
An Analysis of the Marine Aggregate Extraction in Indonesia from Maritime Security Perspective
}

\author{
Aria Cakra Wibawa \\ Indonesian Joint Command and Staff College \\ Indonesia Armed Forces \\ Bandung, Indonesia \\ aria.cakra@seskotni.mil.id
}

\begin{abstract}
The purpose of this article is to provide a legal analysis of marine aggregate extraction in Indonesia from the perspective of maritime security. Maritime security threats cover various illegal activities over the ocean. Current marine aggregate extraction in Indonesia has contributed to a new threat in ocean governance with regard to ocean mining. As the interest from both private companies and governments in a global scale towards the development of ocean mining continues to rise, there is a new arising question as to whether marine aggregate extraction will have negative effects on the maritime security in Indonesia. On the other hand, maritime delimitation as one of the concern of maritime security plays a major role in keeping peaceful relation among adjacent states. As states continue to mine in the ocean, the scarcity of natural resources needed might draw states to further explore and exploit in territories outside their own.

While Indonesia has mining regulations in place, legislative framework concerning ocean mining is not ready yet. Meanwhile, statistic shows that Indonesian mining resources are listed at number 6 in the world. Therefore, responsible governance of seabed mineral developments across the region in accordance with international law is crucial. It is submitted that while ocean mining offers potential benefits for Indonesia, the practice of such activities might be the next frontier of maritime insecurity.
\end{abstract}

Keywords- ocean mining, marine aggregate extraction, Indonesia, maritime security, insecurity

\section{INTRODUCTION}

As the biggest archipelagic state in the world, two third of Indonesia's territory consist of ocean space. Besides serving as one of the largest media transportation, the ocean serves as the biggest place where various natural resources, both living resources as well as non-living resources can be found. Indonesian potential on ocean mining is the greatest among all in the world. The shortage of land-based minerals has forced states to look at ocean minerals both off shore near the coast as well as far as Exclusive Economic Zone (EEZ). Ocean minerals can be found in various depth. In fact there are three layers, including first layer with the depth of up to 250 meters; second layer is between $250-1500$ meters; and third layer is between 1500 meters to 15 kilometres. While ocean mining has occurred for many years, confusion often emerges with regard to deep-sea mining. At this point there should be differences of nearshore mining, deep-sea mining, and aggregate extraction. Ocean mining targeted on aggregates, diamonds, tin, magnesium, salt, sulphur, gold and other heavy minerals has generally been conducted in shallow area near shore or known as near-shore mining, that is less than 50 meters of water depth. Whereas, sea-bed mining targeted on deeper waters for phos phate, massive sulphide deposits, manganese nodules and cobalt-rich crust [1]. Marine aggregate extraction is carried out at short distances from landing ports in waters with the depth less that 50 meters [2]. Such a marine aggregate extraction is usually carried out through dredging methodology.

In terms of International Convention provided for ocean usage, the Law of the Sea Convention 1982 (LOSC) introduces maritime zones, which divide ocean space into several maritime zones horizontally, over which coastal states' sovereignty and jurisdiction vary for each maritime zones. The farther the ocean space is, the less coastal states' sovereignty and jurisdiction will be. In general, such maritime zones distinguish areas within national jurisdiction and areas beyond national jurisdiction. Areas within national jurisdiction consists of internal waters, archipelagic waters (only for an archipelag ic state), territorial sea, contiguous zone, exclusive economic zone (EEZ), and continental shelf [3]. Whereas areas beyond national jurisdiction consists of high seas and the sea-bed and subsoil below, known as the Area [4]. Furthermore, since the contour of the ocean varies between states, ocean minerals can be found within various maritime zones. This is why in examining deep-sea mining the difference should be made between deep-sea mining in areas within national jurisdiction, that is ocean mineral mining conducted within 12 nautical miles from the baselines; and deep-sea mining in areas beyond national jurisdiction [5]. For the purpose of this paper, only ocean mining in areas within national jurisdiction will be considered, specifically on marine aggregate extraction of near-shore mining.

This paper provides legal analyses of marine aggregates extraction in Indonesia from the perspective of maritime security. This paper focuses on the marine aggregates extraction conducted in areas within national jurisdiction bordering neighbouring states' maritime territory. It questions whether such activities will have negative effects on maritime security strategy in Indonesia. It begins with Indonesia's potential on ocean minerals, especially those that lie within Indonesian waters adjacent to neighbouring states such as Malaysia and Singapore. It is followed by examination of Indonesian legislation on mining. It is submitted that while there is no specific national legal 
framework on ocean mining, the practice of such activities might be the next frontier of maritime insecurity.

\section{OCEAN MINING ADJACENT TO NEIGHBORING ST ATES'} MARITIME TERRITORY: MARITIME SECURITY PERSPECTIVES

While there is no universal definition on what constitutes maritime security, for the purpose of this paper maritime security can be defined as states' effort in establishing good order at sea and this includes preventing as well as enforcing laws against various illegal activities at sea. With regard to ocean natural resources, it includes effort in securing ocean natural resources, both living and non-living resources for the welfare of the country. In Indonesia, securing the usage of natural resources only for the sake of its people, was provided within Article 33 (3) of 1945 Indonesian Constitution, which reads "earth, water and natural resources contained therein are controlled by the State and used for the greatest prosperity of the people [6]."

As stated previously, since ocean minerals can be found within various maritime zones, securing ocean minerals means securing them from internal threats as well as external threats. Internal threats in this regard refer to any illegal activities conducted within the areas of national jurisdiction, that is within the limit of 12 nautical miles, such as illegal dredging activities and illegal marine aggregate extraction [7], such as what has occurred in Jakarta, Jambi, Batam and Riau [8]. Whereas external threats refer to potential maritime delimitation disputes with regards to exploration and exploitation of ocean minerals. For instance, minerals mining conducted in Batam. Northern waters of Batam Island separate three adjacent states, which include Indonesia, Malaysia and Singapore. Consequently those states have to agree on maritime delimitation first in order that they are to legally explore and exploit ocean minerals within such waters. Unfortunately, not all points of maritime delimitation have been agreed on those waters [9]. This way, the role of maritime security over those waters would be securing the ocean minerals potential and preserving them only for the greatest prosperity of Indonesian people as envisaged in Article 33 (3) of the 1945 Indonesian Constitution. The map bellow shows geographical location of northern Batam waters which is very close to Malaysia and Singapore:

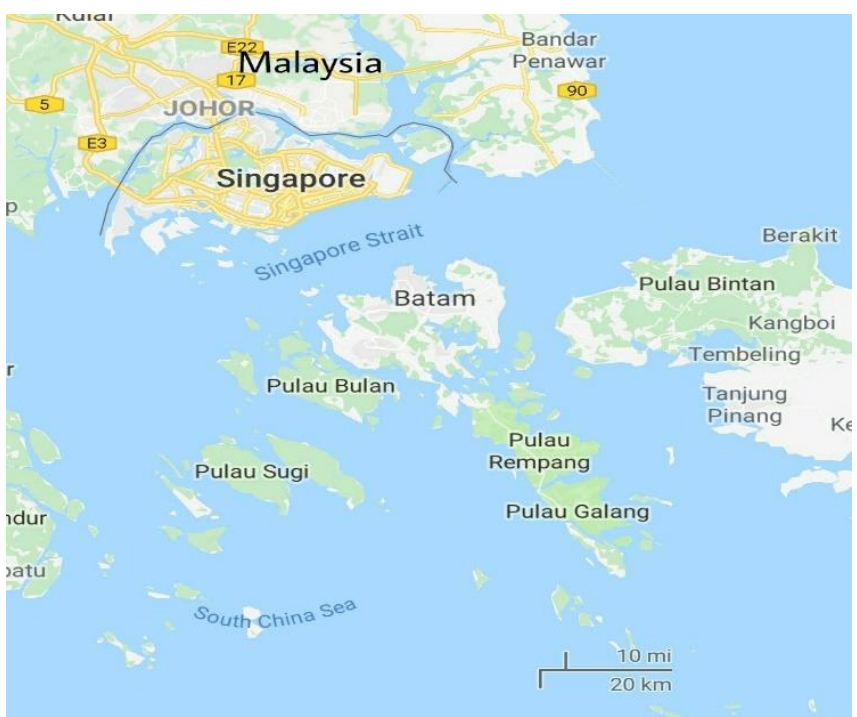

Figure 1: Geographical Location of Batam which shows adjacent territory of Singapora and Malaysia
It is submitted that from the map above ocean mineral activities in the northern Batam waters raises potential conflict among Indonesia, Malaysia and Singapore and this way has added new dimension in the maritime security threats.

Ocean mining in deeper waters has yet never been conducted in Indonesia due to financial support for such activities. However, exploration and exploitation of nearshore has been conducted in several parts of Indonesia. The result found that marine aggregate extraction conducted nearshore is considered as unfriendly mining activities since it affects marine ecosystem and decreases fish production on the affected waters. Many objections raised from environmental activists which question the importance of ocean mineral mining if such activities ruin other potential ocean resources, such as fish and coral reefs [10]. It is further argued that massive marine aggregate extraction should have environmental standard and should make sure that such activities still preserve the ecosystem of marine environment.

The issue of marine mining in fact has been around for quite sometimes. There has been international legal framework in place for deep-sea mining both in areas within national jurisdiction as well as beyond national jurisdiction. With regard to ocean mining in areas within national jurisdiction, Article 77 of the United Nations Convention 1982 or also known as Law of the Sea Convention (LOSC0 gives coastal states the rights to engage in the exploration and exploitation of non-living natural resources of the seabed and subsoil within its national jurisdiction [11]. However, LOSC and other relevant international legal frameworks are silent on the guidance on how coastal states should adopt their national legislation on ocean mining. Although Indonesia does not have specific national legislation on ocean mining, it does not mean that Indonesia does not have Mining Act. Indonesian Mining Regulations are provided within Indonesian Act number 4 Year 2009 on Minerals and Coals (Mining Act 2009). The following section examines whether Mining Act 2009 implicitly refers to ocean mining. In addition, it will decide whether marine aggregate extraction is considered illegal based on Mining Act 2009.

\section{INDONESIAN ACT NUMBER 4 YEAR 2009 ON MinERALS AND COALS (MINING ACT 2009)}

While Indonesian Mining Act 2009 does not specifically refer to ocean mining, Article 6 and 7 indirectly refer to mining activities conducted over the ocean. Article 6 (f) and ( $g$ ) envisages the government authority in approving mining activities in ocean areas within 12 nautical miles [12] and ocean areas beyond 12 nautical miles [13]. In such, it is implied that Mining Act 2009 has acknowledged the division of ocean mining into two categories, including ocean areas within 12 nautical miles and those beyond 12 nautical miles. This arrangement confirms international legal framework with regard to deep-sea mining [14]. Article 6(1) (f) and (g) Mining Act 2009 provides regulation that the government has the authority to give approval for mining activities in ocean areas beyond 12 nautical miles. Article 7 and 8 further envisage that for ocean areas within 12 nautical miles, the authority in giving approval for mining activities is delegated to provincial government and city/ district government. Article 7 (1) (b) (c) and (d) implies that the authority of provincial government is from 4 nautical miles up to 12 nautical miles from the coastline, while Article 8 (2) (a) and 
(b) implies that the authority of city/ district government is up to the maximu $m$ of 4 nautical miles.

Implementation regulation of Mining Act 2009, Government Regulation Number 22 Year 2010 on Mining Areas (Governenent Regulation 22/ 2010) Article 6 (2) further provides that if an ocean area is located between two provincial territories with the distance of less than 24 nautical miles, then the area should be divided equally. While such arrangement seems simple, it becomes more complicated if the ocean area is located between Indonesia and another country. At this point, it should be noted that the limitation of beyond 12 nautical miles for Indonesia as an archipelagic state is different from those of normal ordinary coastal states. In Indonesia, beyond 12 nautical miles can be exclusive economic zone (EEZ) or archipelagic waters. For instance, beyond 12 nautical miles for coastal province located on the northern side of Java, is archipelagic water, over which Indonesia has full sovereignty with only one exception of the existence of foreign vessels' passage. Whereas beyond 12 nautical miles for coastal province located on the southern side of Java, is Indian Ocean or EEZ. As referred to Article 6 (2) of PP 22/ 2010, for northern part of Batam, the province of Riau Archipelago is bordering the ocean space of Singapore and Malaysia. While Indonesian Laws is silent on the mechanism of mining on the ocean areas, some activities of aggregate extraction has been conducted in several parts of Indonesia, namely Jakarta, Riau, Jambi, Batam and Bali. It is unclear whether such activities are considered illegal. Indonesian Mining Act and Government Regulation 22/ 2010 only regulates government authority concerning approval of mining activities according to mining areas determined by regional government, either provincial government or city/ district government. On the other hand, several protests from local community on such activities has arisen since the consequences of the aggregate extraction was considered harmful for marine ecosystem. It is argued that the lack of mechanism in ocean mining cannot be used to justify that ocean mining is not prohibited. In fact, Eko Teguh Paripurno, a geologist expert, argued that land mining mechanism which includes environmental analyses cannot be applied to ocean mining directly [15]. This is because the difference between land and ocean ecosystem. He further argued that aggregate extraction has a bad implication for local communities mosty working as fishermen. Since the ecosystem is polluted, the fish move away from the shore and consequently, fish catching decreases [15].

The lack of legal framework which specifically regulates mining on the ocean, either near-shore mining, such as aggregates extraction, or deep-sea mining resulted in the difficulty of law enforcement. Since ocean mining can be done in almost every maritime zone, thus legal framework on ocean mining should encompass legal framework for ocean mining conducted within national jurisdiction and those conducted beyond national juris diction. [16]

\section{MARINE AGGREGATE EXTRACTION: NEXT FRONTIER TO MARITIME INSECURITY?}

This section discusses correlation between marine aggregate extraction with maritime security. It is argued that the lack of specific legal framework on ocean mining might lead to maritime insecurity. This is also because the difficulties encountered in law enforcement regarding the absence of specific legal references. Once the government approves mining activities, it is unclear which institution has the authority to monitor whether the mining activities carried out are in accordance with the approval given. In addition to this, there are no provisions stating that regarding mining areas adjacent to neighbouring states, bilateral agreement should be made. This might lead to further legal problem with adjacent states.

While there is no universal definition of maritime security, the keywords for maritime security are: preventive and responsive measures, aiming at both law enforcement as a civilian and military requirement and defense operations as a military, in this case naval requirement. Meanwhile, the International Maritime Organization (IMO) draws a distinction between maritime safety and maritime security. The previous refers to preventing or minimizing the occurrences of accidents at sea that may be caused by substandard ships, unqualified crew or other operator's error, whereas the latter refers to the protection against unlawful and deliberate acts conducted at the ocean [17]. In sum, crucial distinction is between man-made and unintentional risks and dangers. Wibawa further elaborates the scope of maritime security threats as shown in this graph below [18]:

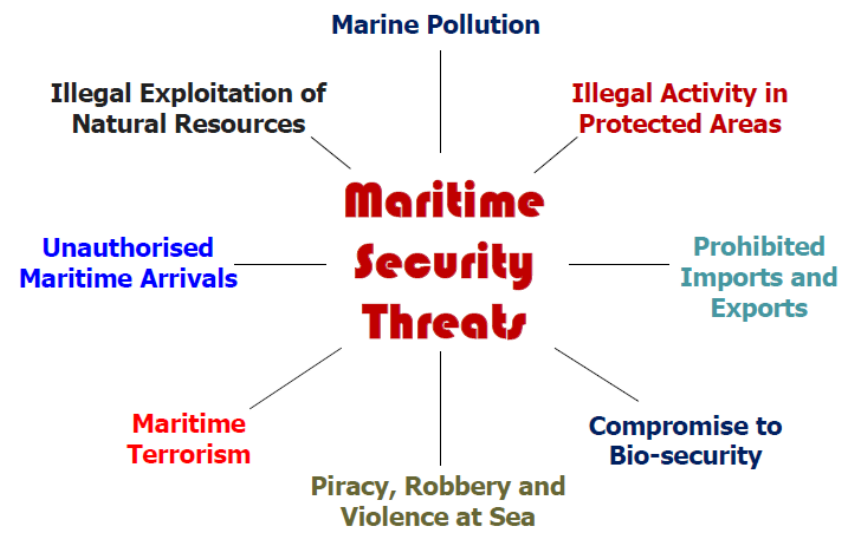

Furthermore, draft on Indonesian maritime and safety policy provides several terminologies relevant to maritime security, which includes brief description on the situation on maritime security and safety [19]. It also defines threats on sovereignty, threats on lawful act on the ocean, threats to navigation as well as to exploration and exploitation of ocean resources. Article 1 paragraph 7 of the draft states that maritime and safety at sea is the encouraging situation in achieving national development purposes through government action supported by active participation from relevant stakeholder in addressing threats/ potential threats while preserving marine environment [20]. Paragraph 8 defines threats to maritime and safety at sea as threats to sovereignty, threats to navigation, threats to exploration and exploitation of ocean resources as well as natural disaster at sea [21]. At this point, emphasis should be made on the matter of marine pollution and threats to exploration and exploitation of ocean resources.

Marine aggregate extraction will affect maritime security regarding pollution and environmental issues, posing threats to ocean resources if the exploration is not conducted properly. and the issue of maritime delimitation will rise if such an aggregate extraction is conducted in ocean areas near other country's ocean areas. In addition, Indonesia, while 
approving on mining activities, should also consider its marine protected area and making sure the exploitation is not conducted over marine protected areas.

While exploration and exploitation of ocean resources such as aggregate extraction may not affect an agreed maritime delimitation between countries, the mining activities might cause further problems to maritime delimitation in areas in which maritime delimitation has not been agreed yet. Although LOSC gives coastal states the right to adopt national laws on ocean mining, unfortunately it does not give guidance on how the adoption of national laws should be done [22]. For exploration and exploitation of ocean resources conducted within national jurisdiction like aggregate extraction which is usually conducted in nearshore areas, appropriate legal framework also needs to be formulated. This is because unregulated aggregate extraction would add more threat to maritime security, especially on the protection of ocean resources and marine environment.

Furthermore, draft revision on Indonesian Mining Act 2009 in fact points out clearly about ocean mining. However, there is still ambiguity in the terminology used. While in its academic paper the terminology used was 'underwater mining', the draft itself uses the terminology 'under-ocean exploration' with no further limitation which part of ocean refers to. The terminology of 'underwater mining' raises question as to whether it include mining conducted on the rivers? [23]

Unclear regulations on ocean mining cons equently brings difficulties in law enforcement. Moreover, there is existing problem in law enforcement mechanism and institutions. As recognized there are various law enforcement institutions in ocean affairs. This paper is aimed to enrich the function of Maritime Security Coordinating Agency (Badan Keamanan Laut/ further stated as Bakamla) and the establishment of regional Bakamla in supporting ocean mining and to make sure the consistency of exploitation and exploration activities with international laws and other general principles of international laws [24]. It is further argued that current operation of Bakamla cannot reach all remote areas in Indonesia and in such, regional Bakamla is needed to monitor every activities on the ocean space. Regional Government does not have law enforcement function with regard to ocean mining, including aggregate extraction. It only has authority in approving mining activities in certain areas of ocean. Regional representatives of Bakamla would assure same vision and mission between central Bakamla and regional Bakamla.

\section{CONCLUSION}

Listed at number 6 in the world on the availability of mining resources, Indonesia is very keen to provide sufficient legal framework in mining. It is argued that since two third of Indonesian territory are covered by the ocean, the biggest mining resources of Indonesia lies beneath the ocean floor. Unfortunately, legal framework which specifically regulates ocean mining is not yet in place. While deep-sea mining, that is conducted beyond national jurisdiction has not been conducted by Indonesia, ocean mining in near-shore, such as aggregate extraction has been conducted in several parts of Indonesia.

Although there is no specific legal framework on ocean mining it does not mean that there is no mining regulation at all. Indonesian Mining regulation is provided by Indonesian
Mining Act 2009. This Act incidentally provides only little arrangement on ocean mining, which only envisages the matter of government approval in mining activities in ocean areas with no further rules and mechanism on how such ocean mining could be done. Thus, it is argued that unregulated ocean mining, especially aggregate extraction conducted in near-shore waters would lead to maritime insecurity. In addition to this, it would add another maritime threat if such aggregate extraction is conducted in ocean areas bordering neighboring states. In such, it is submitted that while ocean mining offers potential benefit for Indonesia, the practice of such activities might be the next frontier of maritime insecurity.

Thus, this paper suggests that Indonesia establish sufficient legal framework in ocean mining both in areas between national jurisdiction and areas beyond national jurisdiction in accordance with existing international laws and principles. Institution of law enforcement of such legal framework should also be considered by the establishment of the regional representatives of Bakamla.

\section{REFERENCES}

[1] Baker, Alen, Offshore Mining Industries, United Nations 2016.

[2] UNEP, "Sand, rarer than one thinks", UNEP Global Environment Alert Service (GEAS) available online at http://na.unep.net/geas/getUNEPPageW ithArticleIDScript.php?article id=110.

[3] Part II-VI of LOSC

[4] Part XI of LOSC

[5] Final Report under FWC MAR E/2012.06 - SC E 1/2013/04, "Study to Investigate the State of Knowledge of Deep-Sea Mining", 2014

[6] Article 33 (3) Indonesian Constitution 1945

[7] Supriharyono, Supriharyono, "Effects of Sand Mining on Coral Reefs in Riau Islands", Journal of Coastal Development v.7 n.2, 2004, 89.

[8] Supriharyono, 2004, Ibid.

[9] Usman Ediar, "Konservasi Potensi Mineral di Perbatasan IndonesiaSingapura, Tinjauan Geologi Kelautan Guna Menunjang Cadangan Mineral Nasional", Pusat Penelitian dan Pengembangan Geologii Kelautan, 2016

[10] Grassnews, "Pasal Mengerikan Tambang Bawah Laut", 2016 available on-line at http//www.grasnews.com accessed on 12 June 2018.

[11] Article 77 of the LOSC

[12] Article 6 (f) Mining Act 2009

[13] Article 6 (g) Mining Act 2009

[14] See generaly Final Report Under FWC MAR E/2012/06 - SC E 1/2013/04, 2014, note [5]

[15] Read further "Pasal Mengerikan Tambang Bawah Laut", gresnews antara, 07 April 2016

[16] BDI-Federation of German Industry, Department of Security and Raw Materials Position Paper, "The Opportunities of deep-sea mining for Germany's raw materials strategy", 2014; See also Rogers, Alex D, "Delving Deeper: Critical Challenges for $21^{\text {st }}$ Century Deep-Sea Research:, European Marine Board Position Paper 22, August 2015.

[17] P.K. Mukherjee and M.Q. Mejia, jr, "The ISPS Code: Legal and Ergonomic Considerations" in M.Q. Meija, jr (eds), Contemporary Issues in Maritime Security, 2003, 33-34.

[18] Wibawa, Aria Cakra, "Keamanan Laut", Public Lecture delivered at Law Faculty, Brawijaya University, 19 March 2014.

[19] Draft on Indonesian maritime and safety policy, Bakamla2017

[20] Article 1 paragraph 7 of The Draft on Indonesian maritime and safety policy

[21] Article 8 of The Draft on Indonesian maritime and safety policy

[22] See further Part XI of LOSC

[23] See generally "Revisi UU Minerba Potensial Rugikan Negara", grasnew, 25 March 2016 available on-line at www.grasnews.com 
Menolak Draft Revisi UU Minerba Versi USDM", available on-line at www.jat am.org accessed on 13 June 2018; Leonard, Lucky, "Inilah Poin-Poin Baru dalam Revisi UU Minerba" available on-line at www.bisnis.com; Widianto, Arif, "Aturan Baru Pertambangan Minerba 2017, 13 Januari 2017 available on-line at https://bolasalju.com accessed on 12 June 2018; "Pasal Mengerikan Tambang Bawah Laut", grasnews 07 April 2016 available on-line at https://grasnews.com accessed on 14 June 2018

[24] Read further Indrajaya, Evalauasi Keamanan Laut Indonesia, Bakamla,2012 